Western University Scholarship@Western

Centre for the Study of International Economic

Centre for the Study of International Economic

Relations Working Papers

Relations

1980

\title{
Monetarism: An Interpretation and an Assessment
}

David Laidler

Follow this and additional works at: https://ir.lib.uwo.ca/economicscsier_wp

Part of the Economics Commons

Citation of this paper:

Laidler, David. "Monetarism: An Interpretation and an Assessment." Centre for the Study of International Economic Relations Working Papers, 8010. London, ON: Department of Economics, University of Western Ontario (1980). 


\section{ARCC}

CENTRE FOR THE STUDY OF INTERNATIONAL ECONOMIC RELATIONS

no.

8010

WORKING PAPER NO. 8010

David Laidler

This paper contains preliminary findings from research work still in progress and should not be quoted without prior approval of the author.

DEPARTMENT OF ECONOMICS

UNIVERSITY OF WESTERN ONTARIO

LONDON, CANADA

N6A 5C2 


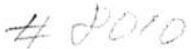 \\ Monetarism: an Interpretation and \\ an Assessment.}

by David Laidler

This paper has been prepared for presentation at a Conference to be held on July 24, 1980 in London, England under the auspices of the Royal Economic Society. I have benefitted greatly from the extensive comments of John Foster, Milton Friedman, John Helliwe11, Geoffrey Kingston, Clark Leith, Thomas Mayer, Ronald Shearer and George Zis, none of whom is to be held responsible for the views that I espouse. The financial support of the Social Science and Humanities Research Council of Canada is gratefully acknowledged. 


\section{Introduction}

Like beauty, "monetarism" tends to lie in the eye of the beholder, and before it can be assessed it must be defined. Though there have been a number of valuable attempts over the years to specify monetarism's key characteristics, I shall not rely upon them in this essay。 Each of them has been heavily conditioned by its time and place of writing, and monetarism has evolved over the years in response to changing circumstances, and in different ways in different places, as new hypotheses have either been developed or absorbed. Thus, I will begin this paper with my own characterisation of Monetarism: Let it be clear that there is a strong subjective element in my perception of that doctrine, and although I hope the reader will not find it capricious, I suspect that not everyone will agree with the amount of emphasis that I lay on particular factors. In my view, the key characteristics of monetarism are as follows:

I. A "quantity theory" approach to macroeconomic analysis in two distinct senses: (a) that used by Milton Friedman (1956) to describe a theory of the demand for money, and (b) the more traditional sense of a view that fluctuations in the quantity of money are the dominant cause of fluctuations in money income。

II. The analysis of the division of money income fluctuations between the price level and real income in terms of an expectations augmented Phillips curve whose structure rules out an economically significant long-run inverse trade off between the variables. 
III. A monetary approach to balance of payments and exchange rate theory.

IV. (a) Antipathy to activist stabilisation policy, either monetary or fiscal, and to wage and price controls, and (b) support for long-run monetary policy "rules" or at least prestated "targets", cast in terms of the behaviour of some monetary aggregate rather than of the level of interest rates.

I. categorises the theoretical core of monetarism as it developed in the 1950s and 60s, II. and III. represent theory developed or absorbed by monetarists since the mid 1960s, while IV. summarises a view of macroeconomic policy issues which, even though it is neither logically implicit in their positive analysis, nor their exclusive property, has remained rather constant among monetarists for the last quarter century.

I will take up each of these characteristics of monetarism in turn in the following pages, but before I do so, let me briefly deal with two propositions that some might feel should be included in the above list. First, non-monetarists have frequently accused their opponents of failing to give any account of the transmission mechanism of monetary policy, and have attributed to them a belief in some mysterious "direct" influence of money on expenditure, while monetarists on the other hand have sometimes referred to a characteristically "monetarist model" of that same transmission mechanism cast in terms of portfolio substitution among a wide variety of assets including reproducible capital, and even perhaps non-durable consumption goods. I believe that this is and always has been a non-issue. The claim that monetarists have failed to specify their transmission mechanism has never been true from the very outset (see, e.g., Friedman and David Meiselman (1963), Friedman and Anna Schwartz (1963), Brunner (1961)), and although 
the mechanism propounded in those papers is a good deal more sophisticated and better grounded in relative price theory than that embodied in the textbook macro models of the 1950s, or in the econometric models of that vintage, there is no essential differences between it and that analysed for example by James Tobin and his associates ${ }^{2}$

Closely related is the matter of "big" versus "small" econometric models. Monetarists are sometimes said to prefer the latter. To the extent that their views about the importance of the quantity of money for the determination of the general price level prompt them to take highly aggregated systems serfously, there is some justice to this claim. Moreover, it is true that early large scale econometric models were not constructed so as to highlight any strong effects of money on economic activity, and it is also true that monetarists criticised them, not so much for being "big" however, as for being Keynesian. However, subsequent developments have clearly shown that "big" models can easily take on some very monetarist characteristics. ${ }^{3}$ At the other extreme, what were the Albert Ando-Franco Modigliani (1965) and Michael De Prano-mayer (1965) papers about if not to show that single equation reduced form techniques could as well produce "Keynesian" as "monetarist" results? In any event, if there is a method of empirical research more frequently associated with monetarist work than Keynesian, it is not small model or single equation econometrics, but National Bureau techniques of business cycle analysis, and the use of such methods has never, to my knowledge been a matter of controversy in this context. ${ }^{4}$ Empirical analysis of all sorts has been used by both sides in the monetarist controversy, and though it has often in specific instances provided something to argue about, there seems to me to be no dividing line between the statistical methodology of monetarists and their opponents about which one can usefully generalise。 


\section{The Quantity Theory of Money}

It has often been said that Friedman's celebrated essay on the Quantity Theory could just as well have been called "The Theory of Liquidity Preference--a Restatement". Harry Johnson (1962) argued that Friedman's work on the demand for money should be viewed as a development of a fundamentally Keynesian capital theoretic approach to monetary theory and Don Patinkin (1969) later documented that it was indeed just that. However, I would stress the word development here, for "Keynesian" though Friedman's model is, it is no more Keynes' model. than Keynes' "Marshallian" theory of income determination is Marshall's theory; and it differed from other developments of Keynes' theory of 1iquidity preference that appeared at about the same time in a number of ways.

First it abstracted from any specific characteristics that money might have because it is a financial asset; Friedman treated money instead "as if" a service yielding consumer durable to which the permanent income hypothesis of consumption could be applied just as Margaret Reid (1962) applied it to housing, or the contributors to Arnold Harberger (1960) did to a variety of other durable goods. In this respect Friedman's approach stands in sharp contrast to the analyses of William Baumol (1952) and Tobin (1956) (1958) as it does in its claim to be a theory of the total demand for money in the macro-economy rather than of some component of that demand. Second, Friedman explicitly recognised inflation as an own rate of return on money and postulated a well determined functional relationship between the expected inflation rate and the demand for money, a relationship whose existence Maynard Keynes (and 
some of his disciples) explicitly denied. (See Roy Harrod (1971).)

Finally, and so obviously that the matter is usually overlooked, Friedman asserted that the demand for money was, as an empirical matter, a stable function of a few measurable arguments. Keynes did not believe that-his empirically stable relationship was the consumption function--and nor did (or perhaps do) many of his British followers. Moreover, pre-Keynesian monetary theorists did not believe in an empirically stable demand for money function either. Though they often enough assumed a constant velocity of circulation that is by no means the same thing, and in any event, they typically did so in order to make their analytic points with the maximum of clarity, and not with the intention of stating a belief about the nature of the real world. It is only with the publication of Friedman's essay that statements to the effect that the velocity of circulation is, as a practical matter, a stable function of a few arguments become important in the literature of monetary economics. In this respect monetarism is a very different doctrine from Classical and Neo-classical economics, no matter what other similarities there may be, though it should be noted explicitly that the econometricians among American Keynesians have not found it necessary to adopt a monetarist 1 abel as a result of contemplating the possibility of the empirical stability of the relationship. 6

Ten years ago it was possible to argue that this characteristic monetarist belief in a stable demand for money function was well supported by empirical evidence as I did in Laidler (1971). However, the last decade has produced a good deal of evidence to suggest that the relationship has shifted in an unpredicted way in a number of countries. There is not 
space to go into details here, but I would be willing to defend the following assertions.

First the instability in question is often presented, particularly in the United States, as a matter of a cumulative deterioration in the ability of the function to track data. This cumulative deterioration is, I believe, an illusion stemming from the use of dynamic simulations of relationships containing a lagged dependent variable. A one time shift of such a function will, as a matter of arithmetic, lead to a cumulative deterioration of its dynamic simulation goodness of fit that should not be read as implying a continuous tendency of the relationship to shift. On the other hand, I do not believe we can safely conclude that such one time shifts in the demand for money function have not occurred, despite the fact, again particularly in the United States, that some formulations of the relationship turn out to deteriorate significantly less than others during the 1970s. When important issues like the stability of the demand for money function begin to depend, for example, on just which interest rate or rates one uses to proxy the opportunity cost of holding money, I believe that the correct conclusion is not that the variable which provides the best fit this time around is the "right" one, but that our knowledge of the details of the relationship is more fragile than we thought. Finally, arguments to the effect that the demand for money function hasn't "really" shifted, that we can restore its stability by taking note of institutional change and redefining "money" so as to take account of its effects, need to be handled carefully. They are relevant to the interpretation of economic history, but the successful conduct of policy requires that specific actions 
be taken vis $\underline{\text { a }}$ vis precisely defined aggregates in order to achieve particular policy goals. To say, after the event, that our policy didn't work because new assets evolved whose existence affected the outcome of our policies in a way that we could have forecast had we only been able to foresee their invention, may be true, but it is not very helpful in enabling us to do better next time, unless the evolution in question was, as it sometimes can be, the predictable outcome of some policy action or other.

Even so, recent shifts in the demand for money function are not a new phenomenon. There is a good deal of evidence, for more than one country, that the demand for money function has evolved over time as the institutional framework has changed. To cite but four examples: Measures of the income elasticities of demand for money have long been known to have fallen significantly in both the U.S. and Britain in the 20th century (see Laidler (1971)); the abolition of interest payments on demand deposits in the United States in 1933 can be shown to be associated with a change in the nature of the demand function for narrow money (see Charles Lieberman (1980)), as can the growth of Savings and Loan Associations in the 1940s (see Cagan and Schwartz (1975)), or in Britain, the introduction of "Competition and Credit Control" in 1971. Such shifts in the demand for money function as we are discussing here may not be new, then, but they are important. Even though the last three examples are of a type that might have been predicted ex ante, the first is not, and in any event they force monetarists to take more notice than they have in the past of institutional change as it impinges upon the demand for money function, and this has important implications for our views on the proper conduct of monetary policy, a matter to which I shall return in Section $\mathrm{V}$ below.

In the traditional vocabulary of economics, the phrase "quantity theory of money" referred to a theory of (or better an approach to the analysis of) 
the relationship between the supply of money and the general price level. The characteristic monetarist belief that variations in the supply of money are the "dominant impulse" (to borrow Brunner's phrase) causing fluctuations in money income is clearly related to this traditional version of the quantity theory, but modern monetarists are more clearcut in their attribution of a dominant causative role to the money supply than were quantity theorists of earlier vintages. 8 The difference here is surely attributable to monetarists' belief in a stable demand for money function, because earlier quantity theorists spent much of their time contemplating the empirical possibility of autonomous shifts in velocity. However, it takes more than a belief in a stable demand for money function to yield the monetarist view of these matters.

Setting aside the important complications that arise in the open economy, there are two ways in which a conventional analytic model of the IS-LM variety can be made to produce "monetarist" results. First in its under-employment form, if, relative to expenditure, the demand for money is insensitive to interest rates then the quantity of money comes to dominate the determination of the level of real income. Now obviously a monetarist must deny that the interest elasticity of demand for money is infinite, and this has been done often and explicitly, but it is mainly in Britain that such a denial has been thought to amount to a distinctively monetarist statement. A number of textbook writers (including myself), have gone to the other extreme and used the assumption of a zero interest elasticity of demand for money to generate monetarist propositions from an under-employment IS-LM mode1. However, Friedman's (1959) study of the 
United States function is a notable exception to the general tendency of demand for money studies--including those of such pioneers of monetarism as Brunner and Meltzer (e.g. (1963))--to find a significant interest elasticity of demand for money, and Friedman's inability to find a significant relationship turned out to be the result of faulty statistical method (see Laidler (1966) and Friedman (1966)). Thus, I do not believe that the presence or absence per se of a statistically significant interest elasticity in the demand for money function has ever been a serious issue between monetarists and their opponents。 If it had been, it is hard to see how monetarists, not least Friedman (1969) could have contributed to the analysis of the welfare costs of inflation, or how Friedman and Meiselman could have accepted their own evidence of the importance of autonomous expenditure as an influence on money income during the depression years with such equanimity. ${ }^{9}$

If we rule out the vertical LM curve, we can still get an IS-LM model to produce monetarist results if we assume full employment, and then postulate that the major source of disturbance is variations in the leve1--or rate of change of--the nominal money supply. With the determinants of velocity, except the expected rate of inflation, thus pinned down at full employment, and with fluctuations in money income thus reduced to fluctuations in the price level, the characteristics of the demand for money function--other than its stability and homogeneity in the general price level and its sensitivity to fluctuations in the expected inflation rate--become quite irrelevant to the relationship between the quantity of money and money income. A Keynesian 
of course would agree, as an analytic matter, with this proposition, but would probably deny what the monetarist would claim: namely that, if the IS-LM model is to be used as a framework for discussion at all--and there are some monetarists, notably Brunner and Meltzer who would not want to use it at any price--then this full employment version of it is frequently the empirically relevant one.

To put matters this way is, in effect, to say that monetarists' belief in the quantity theory as a theory of money income boils down to the view that inflation is caused by an expanding money supply. As a practical matter, I believe that this is not far from the mark, and that much of the spread of monetarism in the last fifteen years stems from its ability to provide a readily comprehensible explanation of inflation along these lines. However, to cast the monetarist approach to the analysis of inflation in terms of a "full employment" IS-LM model does considerable violence to it and is difficult to justify except as a very first approximation. Though monetarists are among those who have written at considerable length about the interaction of the quantity of money and the price level in models where "full employment" is the rule, the models in question have been long-run equilibrium growth models, not versions of short-run IS-LM analysis; in any event the "money and growth" literature and, to a lesser extent, that dealing with "money and welfare", even though it builds on Friedman's formulation of the relationship between the demand for real balances and the expected rate of inflation as a well defined inverse function, is properly viewed, not as an offshoot of monetarism, but as an extension of Patinkin's (1956) theoretical analysis of the classical dichotomy and the neutrality of money to deal with the long-run properties of a growing economy, in the presence of variations in the rate of change of the 
nominal money supply. 10 In dealing with the interaction of the quantity of money, money income, and prices, the essential monetarist contribution has been to postulate the existence of stable relationships among these variables as an empirical matter, and to draw practical conclusions about the proper conduct of short-run stabilisation policy from studying their nature, and the "money, growth and welfare" literature has next to nothing to say about these matters.

When it comes to empirical as opposed to theoretical questions concerning the relationship between money and money income, what was once monetarist heresy is now close to being received orthodoxy. In this respect monetarism has made an important positive contribution to macroeconomics. In the United States it seems now to be widely accepted that the correlation between the quantity of money and money income that long runs of time series data display is not just the result of coincidence, but does in fact constitute evidence for the existence of a causative relationship that has run primarily from money to money income rather than vice versa. The weight of the evidence produced by Friedman and his various collaborators (not to mention predecessors) and the persuasiveness of their arguments, has changed enough minds to warrant the conclusion that, in an important sense, "we are all monetarists" now. Elsewhere in the world, not least in Britain, there has been a similar movement of opinion. Certainly one no longer hears much about velocity being variable "almost without 1imit". However, one does hear more about "reverse causation" in Britain as an explanation of the correlation between money and money income than one does in the United States. (I sha11 take this matter up below). 
Even so, there is more to monetarist doctrine than the view that variations in the quantity of money lead to systematic variations in money income. It also asserts that those variations are going to be primarily in prices rather than real income. Although, as I have already noted, much of monetarism's popular appeal stems from its claim to provide an easily comprehensible theory of inflation, that theory of inflation is by no means universally accepted. The view that the influence of money on money income falls on its real income component and not on prices has constituted a "Keynesian" alternative to the monetarist position on these matters and the "expectations augmented Phillips Curve" has provided a focus for debate about them. $^{11}$ That is why a particular set of beliefs about its nature is a vital ingredient of monetarist doctrine.

\section{III}

The Expectations Augmented Phillips Curve

The notion of a trade off between inflation and unemployment was widely prevalent in Keynesian literature even before William Phillips (1958) and Richard Lipsey (1960) formalised it in terms of what seemed to be an empirically stable functional relationship. Monetarists have long doubted its existence, instead asserting a belief in the "inherent stability" of the private sector in the absence of policy induced monetary disturbances, by which they have usually meant nothing more complex than that the system tends in and of itself to operate at or near "full employment" if policy makers do not upset matters. The papers of Edmund Phelps (1967) and Friedman (1968) provided a framework in terms of which differences of opinion about these matters could be stated 
sharply enough to be confronted with empirical evidence. Although some commentators (e.g., Helmut Frisch (1978)) treat the Phillips curve as providing an alternative theory of inflation to the monetarist approach, that is surely a mistake. In its expectations augmented form, it emerged at the turn of the decade to provide what Friedman (1970) called "the missing equation" in the monetarist model of inflation.

As we sha11 see in a moment it is possible to derive this "missing equation" from two very different theoretical bases, and disagreements here are of quite fundamental importance for macroeconomics. Nevertheless the first round in the debate about the expectations augmented Phillips curve, and the one that was crucially relevant to monetarism, paid little attention to these matters. It was almost entirely empirical because the relationship in question enabled alternative viewpoints about important and pressing policy issues to be formulated and investigated in an easily manageable way. With $\Delta \mathrm{p}$ the inflation rate, $\Delta \mathrm{p}^{\mathrm{e}}$ the expected inflation rate, and y some measure, either direct or indirect, of the deviation of output from its "full employment" level, and v a "catcha11" vector of other influences, random and otherwise, the general form of the relationship may be written as follows:

$$
\Delta \mathrm{p}=\mathrm{gy}+\mathrm{b} \Delta \mathrm{p}^{\mathrm{e}}+\mathrm{v}
$$

A whole spectrum of beliefs about the nature of inflation may be expressed in terms of this simple equation, depending upon the values assigned to its parameters. Thus, the extreme "sociological" view of the determination of the price level, that was widely prevalent in Britain in the early 1970s, 
would predict that the parameters $g$ and $b$ were essentially equal to zero, implying that monetary policies, if they had any effect on money income, would influence real income alone. The behaviour of prices, in this view, was determined by exogenous factors that would all go into the catchall vector v. At the other extreme, the typical monetarist of the early 1970s would argue that $g$ was positive, so that inflation would tend to decelerate relative to expectations in a depressed economy, and accelerate in an over-expanded one. He would also argue that the coefficient $b$ on expected inflation would be equal to unity, and would supplement equation (1) with some formula for the formation of expectations, typically based on the error learning hypothesis, that ensured that, eventually, any constant actual inflation rate would come to be fully anticipated. For him, therefore, any trade off between inflation and deviations of output from full employment was a temporary one which vanished in the long run. The typical "American Keynesian" of the same vintage would agree with the monetarist about the parameter $g$, and about the reasonableness of assuming that expectations would eventually catch up with experience, but would assign a value of less than unity to the parameter b, thus ensuring that though the price in terms of inflation of increasing output was higher in the long run than in the short run, it did not, as the monetarist asserted, ever become infinitely high. ${ }^{13}$ He might also argue that equation (1) omitted to mention explicitly many factors that in particular times and places might have an important influence on the inflation rate, and which it will suffice here to think of as being captured in $\mathrm{v}$. 
There is not space here to survey the extensive empirical literature that these issues generated, but its upshot may be summarised easily enough: the evidence that the inflation rate tends to slow down relative to expectations in a depressed economy, and to speed up in a booming one, is overwhelming so that the notion of inflation being independent of the behaviour of aggregate demand is hard to sustain. To the extent that differences of opinion here ever set monetarism apart from other points of view--and I think they probably did in Britain, though not in North America--then surely we have here another case of "we are all monetarists now". 14

On the matter of the role of the expected inflation rate, there has also been a swing towards the typically monetarist belief that in the long run there is no economically significant inflation-output trade off. The more rapid inflation of the 1970 s has provided empirical evidence to support this belief, in a way that the mild inflation of earlier decades did not. There is still disagreement, however, about whether the "1ong-run" tendency asserts itself quickly enough in fact to disqualify policy from attempting to exploit such a trade off in the short run. As to the importance of the influence of "other" factors on the inflation rate, as I read the current state of opinion, there is also more of a consensus about the facts than there was. Monetarists are willing to agree that factors such as the activities of OPEC and the Anchovies, or sudden changes in the level of indirect taxes, can affect the behaviour of the price level "temporarily" against the background of long-run trends determined by monetary factors; Keynesians, particularly American ones, in their turn are now willing to agree 
that the long-run trend of inflation may well be determined by monetary factors while continuing to stress the importance of special factors for the short run. Here again though, as we shall see later, agreement does not extend to policy questions. Moreover, as we shall now see, there is much less agreement about the theoretical basis of the Phillips curve than there is about its empirical properties.

As originally analysed by Lipsey, the Phillips curve dealt with the reaction of the level of money wages to the existence of a general condition of excess demand for labour in the economy, and therefore of the general price level to the excess demand for goods. Excess demand was conceived of, not as a purely ex ante notion such as we meet in theoretical analyses of Walrasian tâtonnement, but as a realised quantity such as appears in models of economies made up of markets characterised by sticky prices. In their original critiques of the Phillips curve, Friedman (1968) and Phelps (1967) both concentrated on the point that disequilibrium in the 1 abour market might be expected to bring pressure to bear on real wages rather than on money wages per se, and that what would happen to the latter would therefore be critically influenced by what was thought to be happening to the general price level. Each of them, though Phelps more explicitly so than Friedman, treated unemployment as a quantity signal that conveyed to economic agents the desirability of varying prices, and hence seemed to be providing a crucial correction to what remained a fundamentally Keynesian approach to the analysis of wage and price stickiness. 15

On the other hand, most of the contributors to the well-known Phelps (1969) volume started from a very different theoretical basis to provide an explanation of the interaction of output and prices, though the 
similarity of their conclusions to those stated by Phelps and Friedman at first distracted attention from what in retrospect was the much more important theoretical matter of different premises. According to this alternative approach, which was anticipated by Irving Fisher (1911), the expectations augmented Phillips curve is in fact an aggregate supply curve. Equation (1) is derived from

$$
y=\frac{1}{g}\left(p-p^{e}\right)
$$

combined with the following definition of the expected rate of inflation

$$
\Delta \mathrm{p}^{\mathrm{e}} \equiv \mathrm{p}^{\mathrm{e}}-\mathrm{p}_{-1}
$$

Brunner and Meltzer were quick to adopt this interpretation of the expectations augmented Phillips curve. They had already developed a view of the transmission of monetary impulses in asset markets that stressed the role of relative prices as signalling devices, and found it easy enough to extend that line of reasoning to the markets for output and labour services as well (see Me1tzer (1969)). ${ }^{17}$ By now there can be no doubt that this aggregate supply curve interpretation of the inflation employment interaction is the dominant one among monetarists. However, not all monetarists have accepted it [see, e.g., Cagan (1979)], and as will be apparent from the following pages, it raises issues that go well beyond the traditional subject matter of the monetarist debate.

To say that the Phillips curve is an aggregate supply curve is to say that fluctuations in output and unemployment in response to price level variations represent the voluntary choices of individuals operating in markets which are continually clearing. Since voluntary choices made on the basis of erroneous expectations are by no means the same thing as 
choices that lead to the outcome which agents would have desired, this is not to deny that deviations of output and unemployment from the "natural" levels they would attain were expectations fulfilled represent a serious problem. ${ }^{18}$ However, it is to locate the cause of unemployment, not in the failure of markets to bring together all willing buyers and sellers in ex ante mutually satisfactory trades, but rather in a failure of markets (and other social institutions as well perhaps) to convey sufficient information to enable the expectations upon which those trades are based to be formed accurately in an economy subjected to stochastic shocks.

If fluctuations in output and employment about their natural rates are the result of the failure of expectations to be realised, the manner in which expectations are formed must play a vital role in their analysis. That is why the rational expectations hypothesis is a natural supplement to the aggregate supply curve interpretation of the Phillips curve. If agents suffer losses in utility as a result of making expectational errors, they have an incentive to use all available information in forming their expectations up to the point at which the marginal benefit from improving their accuracy equals the marginal cost of doing so. The rational expectations hypothesis does not say that every agent's expectations are always as accurate as they would be if he were equipped with a "true" econometric model of the economy in which he operates (though it is sometimes convenient to formulate it that way in analytic and empirical exercises), but it does say that his expectations will not systematically be wrong over time and to that extent will resemble those generated by such a "true" mode1. An agent who forms expectations in a manner that leads to systematic error will find himself 
persistently making the wrong choices: hence in the very course of his market activities, he will be provided gratis with the information necessary to eliminate that systematic error.

If each individual makes only random errors in forming expectations, two questions naturally arise: how does it happen that at a particular moment the expectations of a predominant number of agents in the economy should be in error in one particular direction so that aggregate output and employment come to deviate from their "natural rates"? and how does it happen that the fluctuations in output and employment which are observed in any actual economy come to display that pattern of serial correlation summarised in the term "business cycle"? The answer to the first question given by Lucas (1972) is by now well known. If individuals have more up-to-date information about the money prices that rule in the markets in which they operate as sellers than about others, then in order to assess the pattern of relative prices upon which their quantity decisions rest, they must form expectations about the behaviour of other money prices. An unforeseen shock affecting the whole economy which leads to a change in the general price level will influence individual money prices, and will have its consequences everywhere misread as reflecting relative price changes. Hence quantities supplied will everywhere change.

If that was all there was to it, output and employment fluctuations would be random over time. However, if there are time delays in getting information to agents, if there are costs of adjusting output decisions once taken, or if some of the goods over-produced in error in the face of a positive unexpected shock to the price level are durable, then the effects of that shock will persist over time。 19 By the time its effects on output have petered out there 
will be too many durable goods in the economy--capital will be "too deep"--and the marginal productivity of labour in durable goods producing industries thus will fall. If workers prefer to take extra leisure when their marginal productivity is low, and if the price system operates so as to inform them of when that is the case, there will be a voluntary fall in the level of employment that will persist until the structure of the economy's capital stock is restored. The objection to this explanation of the cycle that it predicts more wage variability than we observe in the real world can be countered by arguments to the effect that firms and households find it mutually beneficial to enter into wage contracts under which wages do not instantaneously fluctuate in tune with the marginal productivity of 1 abour, but under which firms are permitted to lay off workers in such a way that the latter still take more leisure at times when their marginal productivity is unusually low, even though the behaviour of wages no longer signals the fact.

Readers will find the last paragraph reminiscent of the Austrian business cycle theory of the 1920s and 1930s, and that is no accident. It is the Austrians, and not, as Solow (1980) has suggested, Pigou, who are the predecessors of Lucas, Sargent and their associates. Like Ludwig von Mises and Friedrich von Hayek, they have set themselves the task of producing a theory of the business cycle that is firmly based on the notion that all market phenomena represent the harmonious outcome of the voluntary choices of maximising individuals. However these neo-Austrians have gone beyond their predecessors to produce a theory in which output and employment as well as prices fluctuate as a result of such voluntary choices. Whatever we may think of the empirical relevance of that theory, and its proponents show an admirable, and un-Austrian, willingness to submit their ideas to empirical tests, we must surely agree that its very construction represents an intellectual achievement of the highest order. ${ }^{20}$ 
One can admire a theory without agreeing with it, and there are many including myself who would challenge the basic assumption upon which the analysis just discussed is based, namely that it is legitimate to model the economy "as if" markets always clear. It is one thing to agree that commodity and asset markets dominated by specialist traders ought, and indeed do, display the characteristics associated with continuous clearing and rational expectations, and quite another to attribute similar characteristics to the markets for many components of final output, and above all to the labour market. One may follow Hicks (1974) in distinguishing between "flexprice" and "fixprice" markets, assign the labour market to the latter category, and argue that the interaction of inflation and unemployment is best analysed on the premise that the Phillips curve represents the disequilibrium response of prices to a mismatching of supply and demand.

of course the "neo-Austrians" are well aware that there is no Walrasian auctioneer to set prices, and no recontracting to ensure that trade only takes place at market clearing prices; but they do assert that individual agents--or their representatives--are acute enough in their bargaining to ensure that money wages and prices universally behave "as if" markets operated along such Walrasian lines, that they perceive the possibility of realising mutual gains by adjusting wages downward when excess supply turns up in the market in which they are operating, and act upon that perception. ${ }^{21}$ However one can have no difficulty accepting the proposition that, even in labour markets, if it is mutually beneficial to lower money wages (or their rate of change), agents will discover this and wil 11 agree to do so, but still find it hard to understand how the relevant information is conveyed to the 
agents in question without the intervention of quantity signals. In a Walrasian market, the auctioneer can discover that price is too high by adding up notional supplies and finding out that they exceed notional demands, to use Robert Clower's (1965) terms, but how can participants in any actual labour market find out that money wages there are too high without some of them discovering first that they are unable to sell all the services that they would like at the going rate?

If adjustments in the level (or rate of change) of money wages and prices to aggregate demand shocks are anything other than instantaneous, then markets fail to clear, trade takes place at false prices, and quantity signals, perhaps amplified by multiplier effects, become an integral part of the mechanism whereby monetary changes are transmitted to the behaviour of the price level. This line of analysis is as "Keynesian" in spirit as the clearing markets approach is "Austrian", and its existence permits one to subscribe to the expectations augmented Phillips curve without also being committed to a clearing market rational expectations approach to the analysis of economic fluctuations. Moreover, the approach in question does not differ from the clearing market view in denying that individuals perceive and then engage in all available mutually beneficial trades. It simply denies that they do so infinitely rapidly. I do not see why, as for example Barro (1979) has recently suggested, to postulate an infinite speed of price adjustment in the face of excess demand or supply is to conform to sound microeconomic principles, and to postulate anything significantly slower is to propose an "ad hoc non-theory".

Nevertheless the non-clearing market approach to analysing inflation employment interaction cannot be reconciled with a fully fledged application of the rational expectations hypothesis. If the terms $\Delta \mathrm{p}^{\mathrm{e}}$ on the right 
hand side of equation (1) does represent a rational expectation of the rate of inflation at which markets will continue to clear, then the term $y$ must represent a purely random deviati on of output from its equilibrium level, and in that case there could be no reason for the actual inflation rate to respond to it. The existence of an empirically observed short-run correlation between output and inflation makes it impossible simultaneously to adopt a. rational expectations interpretation of the $\Delta \mathrm{p}^{\mathrm{e}}$ term in the expectations augmented Phillips curve and a non-clearing market interpretation of the relationship as a whole. However, if output fluctuations convey information to agents about the appropriate behaviour of prices as the non-clearing market approach suggests, they may be regarded as constituting one of the ingredients of agents' expectations; in that case the term $\Delta \mathrm{p}^{\mathrm{e}}$ should be thought of as summarising influences upon expectations other than quantity signals. To say this begs the question of what those "other influences" on expectations might be, but leaves open the possibility that the same type of information to which the rational expectations hypothesis draws our attention could be incorporated without difficulty into models based on the non-clearing-market approach. Observations on the past behaviour of the money supply, for example, might well provide agents with information about the appropriate way to set prices, and might be included among those "other" influences, as might in an open economy, variations in prices ruling elsewhere in the world economy, variations in exchange rates, and so on ${ }^{22}$

The non-clearing-market interpretation of the Phillips curve needs to be reconciled with the basic facts of the business cycle. Once given, why do output signals not result in an immediate adjustment of prices to a market clearing level? The answer here is straightforward--a quantity signal 
will lead to a response in price behaviour only to the extent that agents believe that the shock which gave rise to it will persist into the future. Inability to disentangle short term from persistent shocks will lead to a tendency to under-react to quantity signals, and hence to cause them to be drawn out over time. I would conjecture that the Austrian style arguments about the role of errors made with respect to the production of durable goods in the business cycle can be superimposed upon this fundamentally Keynesian explanation of the persistence of output fluctuations should anyone wish to do so. 23

Now in the last few pages I have shown that theoretical analysis of the interaction of output employment and prices in terms of an expectations augmented Phillips curve has proceeded along two very different lines. However, I believe that it is a mistake to regard debate about these issues as simply the latest round in the monetarist controversy. Though Monetarists and Keynesians are in much closer agreement than they were about the empirical stability of the demand for money function, and about the empirical nature of output-inflation interaction, they still take the same diametrically opposed views on the proper conduct of macroeconomic policy that they did a quarter century ago, and divisions of opinion here do not necessarily coincide with differences of views about the theoretical basis of price-output interaction. I think it best to regard the policy debate as a continuation of the monetarist controversy, and to recognise disputes about the theoretical basis of the Phillips curve as dealing with a new set of issues. ${ }^{24}$ Before I turn to a discussion of the policy aspects of the monetarist controversy, however, it is convenient first to discuss the role of the monetary approach to balance of payments and exchange rate theory in the evolution of monetarism. 
The Monetary Approach to Balance of Payments and Exchange Rate Analysis

To treat the balance of payments, or the exchange rate, as being determined by the interaction of the supply and demand for money both at home and abroad as much represents a revival of the English classical tradition as it does an extension of monetarism. Even so, in my view the monetary approach does differ in important ways from classical analysis, and does provide us with more than an alternative framework for generating already well known predictions, and the very characteristics of the approach that thus distinguish it are in fact borrowed from monetarism. 25

First, advocates of the monetary approach postulate the existence of a stable demand for money function, not just as a working simplification, but as an empirical hypothesis; it is this monetarist hypothesis that transforms the approach from an accounting framework into a body of substantive theory. Second, particularly in early statements of the doctrine, its proponents tied down the real income argument of that function by assuming full employment but, as in the closed economy case, it soon proved possible to replace the "full employment" assumption with an expectations-augmented Phillips curve approach to price-output interaction. ${ }^{26}$ Third, and equally important, the monetary approach provided the means whereby monetarist propositions, about policy as well as about the interpretation of recent economic history, could be made relevant to economies other than the United States which, under the Bretton Woods system, was about as close an approximation to a closed economy that was also a separate political entity as the world has ever seen. Monetarism thus only came to be important outside the United States, not least in Britain, in alliance with the monetary approach to balance of payments analysis. 
Until 1971 the world was on a system of fixed exchange rates against the United States dollar. Under such a system the existence of a stable demand for money function, whose arguments are beyond the direct control of the domestic authorities, implies that the money supply is an endogenous variable that must adjust to demand. Given this insight, evidence that suggests, for example in the United Kingdom in the 1950s and 1960s, that causation seems to have run predominantly from money income to money, rather than vice versa, is no embarrassment to a monetarist provided that he is also willing to attribute most of the variation in money income to causative factors originating abroad. Moreover, although the expectations augmented Phillips curve tells us that in general we should expect to find no stable inverse trade off between inflation and unemployment, down to 1967 post-war United Kingdom data do display just such a well determined relationship, and this fact needs explaining. The monetary approach to balance of payments analysis suggests two complementary reasons why this should be the case. First it notes that, so long as a fixed exchange rate is to be maintained, the prices of tradeable goods sold domestically are going to be determined in the long run, not domestically, but on world markets, and from this it follows that the domestic price level's long-run behaviour is going to be constrained by the behaviour of prices in the world at large. Economic agents do not have to be more than merely sensible to perceive this fact and to incorporate it into their expectations. If world prices are relatively stable, and they were until the 1 ate 1960 s, then so are inflation expectations, and our expectations augmented Phillips curve, equation (1), no matter how we interpret its microeconomic origins, will predict that the data will generate a stable inflation unemployment trade off.

This explanation of the existence of a stable inflation unemployment trade off in post-war Britain is an important component of what may fairly 
be called monetarist hypotheses, about the nature of the stop-go cycle in the 1950s and 1960s and about the degeneration of that economy's performance in the 1970s, which contrast strongly with conventiona1 "Keynesian" accounts of the same phenomena. The latter begin from the proposition that Britain has a peculiarly high marginal propensity to import, so that, under the Bretton Woods system, attempts to run the economy at a high degree of capacity utilisation, though they produced only a small and on the whole acceptable amount of inflation, were frustrated by balance of payments pressure which forced a revisal of policy. The monetarist hypothesis about stop-go, on the other hand, has it that high levels of demand were associated with high rates of domestic credit expansion which, under fixed exchange rates, generated balance of payments problems in large measure as an alternative to domestic inflationary pressure. The conventional view seemed to imply that Britain's economic performance could be improved by adopting exchange rate flexibility and allowing a depreciating currency to offset the balance of payments effects of a high propensity to import. With a flexible exchange rate, the economy could be run at a higher level of capacity and could grow more rapidly without interference from a balance of payments "constraint". According to this view a series of exogenous shocks and the autonomous activities of trade unions undermined a basically well-founded strategy when it was adopted in the 1970s。 The monetarist view, on the other hand, argues that the adoption of exchange rate flexibility replaced a balance of payments problem with a domestic inflation problem when expansionary policies were pursued, and did nothing to influence the economy's ability to sustain either a higher level or rate of growth of real income. For the monetarist, therefore, the deterioration of 
British economic performance after 1972 was the predictable (and predicted) consequence of a policy of expanding aggregate demand against a background of exchange rate flexibility. 27

Now the monetary approach to balance of payments analysis does far more than make monetarist analysis relevant to Britain. It also permits the explanation of the international spread of inflation in the late 1960s in terms of the repercussions in the world economy of United States monetary expansion, and it treats the breakdown of the Bretton Woods system as the clumination of this process. However, it is only fair to note that such analysis performs less well in the face of the behaviour displayed by the international monetary system since exchange rates began to float in the early 1970s. The prediction that the behaviour of exchange rates can fruitfully be analysed as if determined in efficient asset markets does seem to be supported by the data. However, a basic postulate of the monetary approach is that the equilibrium value of the exchange rate between any two currencies reflects purchasing power parity. Just as data generated under fixed rates show that the price levels of particular economies can display considerable autonomy for substantial periods of time, so under flexible exchange rates systematic and persistent deviations of exchange rates from purchasing power parity do seem to be possible. Though purchasing power parity considerations underlie the behaviour of long period averages of data, implying that, ultimately the terms of trade between countries are independent of monetary factors, there seems to be ample room for short run deviations from the long run pattern. Just why this should be the case, and what explains the patterns of such deviations as we observe, are important and, at the moment, open questions. ${ }^{28}$ 
Be all that as it may, the present regime of flexible exchange rates came into being because the authorities in various countries came to believe that they could not control such politically important variables as domestic inflation and unemployment while continuing to adhere to the Bretton Woods arrangements. The diversity of inflation rates among countries since 1971 certainly suggests that there is some merit to the view that the adoption of flexible rates allows such variables to have their behaviour predominantly determined at home; and long before the $1970 \mathrm{~s}$, monetarists, not least of course Friedman, argued that the adoption of exchange rate flexibility was a necessary prerequisite to the pursuit of monetarist policies in individual countries. In the 1970 s we have seen the emergence of conditions under which individual countries could implement independent monetary policies, and as I have suggested above, it is mainly on the matter of policy prescriptions that sharp differences between monetarists and their opponents persist. I shall therefore devote the penultimate section of this paper to a discussion of these matters。 


\section{Policy Issues}

As we have seen, when it comes to propositions about the demand for money function, the relationship between money and money income, and output inflation interaction, there is a real sense in which "we are all monetarists now". The issues that nowadays distinguish monetarists from their opponents concern the conduct of economic policy. As he did in the 1950 s the monetarist still wants fiscal policy to stick mainly to its traditional tasks of influencing resource allocation and the distribution of income and wealth, and monetary policy to adhere to some simple rule under which the monetary aggregates do not react to short-run fluctuations either in real output or prices; the Keynesian on the other hand is still a proponent of activist stabilisation policy.

These policy issues are not independent of the theoretical questions that we have discussed earlier, and indeed, much of the current popularity among monetarists of the-neo-Austrian approach to the analysis of price-output interaction stems from the erroneous belief that it provides the only sound basis for skepticism about the effectiveness of activist stabilisation policies. Many Keynesians focus their attacks on that same piece of analysis in the belief, just as erroneous, that if they succeed in refuting it, they also succeed in restoring the case for activist stabilisation policy. Now the approach in question does indeed deny the possibility of such policies being effective. It tells us that output and employment can be influenced by policy only to the extent that it causes prices to vary in a way that agents in the private sector do not foresee. The rational expectations hypothesis tells us that if such effects were systematic, the private sector would discover the fact, adapt to it, and thereby render policy ineffective. It follows at once that 
the only macroeconomic policy that can influence income and employment is a purely random one, and no supporter of "fine tuning" could possibly recommend that.

The argument just sketched out is logically watertight. So is the counter-argument that, if inflation-output interaction reflects the role of quantity signals in the mechanism whereby various shocks, including those imparted by policy, have their effects transmitted to prices, the way is opened for monetary and fiscal policy to exert a systematic influence upon output and employment. However, there is much more than this to be said about the feasibility and desirability of activist policies. If there was not, how could it be that Friedman (1960) was able systematically to state his views on policy more than a decade before Lucas (1976) and Sargent and Neil Wallace (1975) developed the theoretical arguments that are now so widely regarded as the only logical underpinning of those views? The Lucas-Sargent-Wallace analysis certainly provides a sufficient basis for monetarist policy prescriptions, but it not a necessary basis for them: it is one thing to say that the world is so structured that policy can systematically influence output and employment in the short run and another thing altogether to say that policy makers have enough knowledge to use that ability in a way that will be beneficial.

If it is agreed that in the long run the Phillips curve is essentially vertical--or perhaps even positively sloped if allowance is made for super-nonneutralities--then that certainly does not rule out the possibility of the economy slipping below its natural rate of output in a short run that may be of considerable duration, or the possibility that there exists an appropriate menu of monetary and fiscal policies that might hasten its return to that natural rate without generating any serious costs during the transition. As a first step to exploiting this possibility though, those in charge of policy would need to know 
what the natural rates of output and employment actually are. As a second step, they would need accurate information upon where the economy actually is, and where it would move in the absence of a policy change, not to mention at what pace. Armed with this not inconsiderable amount of information, policy makers would know that they were in a position where it might be useful to deploy some policy measure or other. To design the policy would of course require them to know about the size and time path of the economy's response to the measures they might take, factors which even the loosest application of the rational expectations idea tells us are likely to be influenced by the policy measures themselves.

Now I will readily agree that we have the mathematical and statistical tools available for tackling the design of stabilisation policy along the foregoing lines, and I also agree that our econometric models contain answers to all the quantitative questions that I have just raised. However the conclusion that I draw from all this is that we are probably rather good at finetuning econometric models. One can rest the monetarist case against activist policy on the proposition that markets always clear and that expectations are rational, but one can also rest it on the much more down to earth proposition that we are too ignorant of the structure of the economies we live in and of the manner in which that structure is changing to be able safely to implement activist stabilisation in the present environment, or in the foreseeable future. Among the penalties for making errors in fine tuning that concern monetarists are those that come in the form of uncomfortably high and perhaps accelerating inflation that would result from setting over-optimistic targets for employment and output. Thus, if there is something in the policy environment that weakens the ability of the inflation rate to accelerate, the penalties for such errors are milder, and the case against fine tuning developed 
above can be softened a little. In the 1950s and 1960s, there can be little doubt that the British authorities did succeed in fine tuning income and employment variables within the rather narrow bounds laid down by what then appeared to be balance of payments constraints. The monetarist interpretation of that period implies that the background of monetary stability implicit in the commitment to a fixed exchange rate was the real constraint on how far fine-tuning policy could be pushed and also that it provided the necessary conditions for its limited success. However the fact remains that the experience in question does show that a limited degree of fine tuning is feasible if only a background of long-run price stability is assured, and is seen to be assured.

It is hard for a monetarist to see how one could avoid assigning to monetary policy the role of providing that necessary assurance. ${ }^{30}$ A fixed exchange rate regime is one way of tying down monetary policy, and the adoption of some sort of a money supply growth rule would be an alternative. But this means that fine tuning would have to be by fiscal policy. Such a conclusion will be of little consolation to American Keynesians who are forced by the inabllity of American institutions reliably to deliver rapid changes in fiscal variables to assign to monetary variables a far more important role in stabilisation policy than their British counterparts ever did. However it may do a little to cheer up the British, for whom a return to the days of "never had it so good" might be a welcome relief from the consequences of "going for growth".

As should be apparent from the last few paragraphs, I regard the question of whether governments should or should not indulge in a limited amount of fiscal fine tuning as a secondary issue for monetarists. ${ }^{31}$ Related questions concerning public sector borrowing and the share of the public sector in 
National Income are even more peripheral to the monetarist debate. No matter what the public perception of these matters might be, I insist that monetarist doctrine tells one that there are severe limits to the extent to which public sector borrowing can be financed by money creation, and beyond that has nothing to say about whether a "high" or "low" level of such borrowing is in and of itself desireable. Similarly monetarism offers no guidance as to how big the public sector of any economy ought to be. It is a macroeconomic doctrine and the issues at stake in debates about the size of the public sector, the welfare state, and so on are fundamentally microeconomic in nature.

Monetarism has had a good deal to say about wage and price control policies however. It has opposed them, not just for ideological reasons, but for the much more down to earth reason that they have not been expected to work. ${ }^{32}$ This position has been mainly and justifiably defended on the basis of empirical evidence: in the post-Korean war period it is hard indeed to find any wage-price control scheme that has not produced disappointing results over any period longer than a few months. However monetarists have also sometimes opposed controls on theoretical grounds, particularly in the context of open economies. They have noted that under fixed exchange rates the behaviour of world prices and hence the domestic prices of traded goods cannot be controlled by domestic regulations, any more than can the money supply. They have also pointed out that under flexible rates, though the money supply is under control, neither the exchange rate nor world prices can separately be regulated. In either case in an open economy wage and price controls inevitably impinge upon "the domestic component" of the price level and are hence policies towards relative prices. For that reason, they cannot for long influence the behaviour of the general price level, unless they are accompanied by a battery of quantitative restrictions, not 
least on foreign trade, that very few of their advocates have been willing to contemplate.

In the 1960s wage and price controls came to be regarded as an alternative to monetary policy in the control of inflation, and in the early 1970 s serious attempts were made in both Britain and the United States to use them as such. In both cases the attempts failed sufficiently dramatically that the proponents of controls now regard them at best as supplementary devices to be deployed in harmony with more traditional demand side policies rather than as a serious alternative to such measures. Though such a viewpoint stops short of the blanket opposition to controls that, along with other monetarists, I would still be willing to defend, it does represent a substantial move in a monetarist direction from positions taken a decade ago. Here, as in other instances, much of the heat has gone out of the monetarist controversy. 33 There is more to practical monetarism than skepticism about fiscal fine tuning and opposition to wage and price controls. Its key positive tenet is that monetary weapons should be assigned to the attainment and maintenance of long-run price stability, and hence that those same monetary weapons not be used for fine tuning purposes. In this respect, as with the other components of the doctrine which we considered earlier, there has been a considerable growth in the acceptance of monetarism. Propositions about the desirability of setting rules and targets for the growth of monetary aggregates are now commonplace in the statements of Central Banks. If monetarists complain-and they do--about the failure of Keynesian policies since the mid 1960s, then imple fairness requires them to say something about the lessons that they have learned about the viability of their own policy proposals from what many observers believe to have been widespread and sustained efforts to apply them during the 1970s. 
The first thing to be said on this score is that the case for monetary growth rate rules, as initially stated by Friedman (and Edward Shaw) was put in terms of the capacity of such a policy to maintain stability in an already stable economy--it was a policy prescription for staying out of trouble. However it has been only since our economies have found themselves deeply in trouble that monetarist policy proposals have attracted the attention of policy makers. There is much less unanimity among monetarists about how to tackle the problem of restoring stability than there is about how to maintain it. Though all monetarists would agree that a return to a modest growth rate of some monetary aggregate or other is the long-run goal, the neo-Austrians would favour a rapid return to such a rule, while tiose of us who take a more traditional view of the nature of the Phillips trade-off have advocated "gradualism."

Unless we take the cynical view that the rhetoric of central bankers bears no relationship to their intentions, we must conclude that in a number of places attempts have been made to implement gradualist policies. There are two questions to be asked about those attempts: first, is it the case that those attempts have resulted in a systematic and gradual reduction in the rate of growth of any monetary aggregate? and second, if such attempts have anywhere been successful, did that success lead to a reduction in the inflation rate? As is well known, policy has in the main failed on the first count. Only in Canada, to the best of my knowledge, have the authorities set, and on the whole succeeded in achieving, pre-stated monetary growth targets over an extended period. It is equally well known that the single most important reason for this failure, at least in the United States and Britain, has been the unwillingness of those in charge of monetary policy to give up setting interest rate targets when they adopted targets for the money supply, 
combined with a proclivity to stick with the interest rate target when the two came into conflict, as they inevitably had to sooner or later. This has not been universally the case, however. Germany and Switzerland have had difficulty sticking to money supply targets because of concern with the behaviour of the exchange rates rather than interest rates, as Sumner (1979) has noted, while political concern over the exchange rate and interest rates is, currently, a serious threat to the continuation of the Canadian experiment, just as it promises to bear fruit.

It would be easy enough to argue in the light of all this that recent experience offers essentially no test of monetarist gradualism, but that seems to be going too far. Monetarists have usually treated questions of income distribution and resource allocation as separate and distinct from those of monetary policy. This dichotomy is a useful one when the problem for monetary policy is to maintain already existing stability, but can all too easily lead one to neglect the way in which monetary policy interacts with allocation and distribution when its implementation requires sharp (albeit temporary) increases in interest rates. A key factor here is of course the political importance of the housing market, and of the behaviour of mortgage interest rates. In retrospect, it is clear that monetarists did not do a very good job of educating policy makers--both elected and otherwise--about the problems that adopting monetarist policies would generate in this area. Some of us did raise these matters, but apparently not loudly enough. ${ }^{34}$ High interest rates have turned out to be more difficult for politicians to deal with than high unemployment rates, and this was not widely foreseen.

There are also technical problems with implementing monetarist policies. The manipulation of interest rates as the centrepiece of monetary policy long antedates the Keynesian revolution, and was quite appropriate in economies whose monetary rule was to maintain convertibility into gold or some other currency at a fixed price. However the day to day operating procedures of central banks, the very organisation of their decision making processes, not 
to mention the structure of the private markets in which they operate are all geared by force of tradition to making and implementing decisions about interest rates. Although monetarists have done a great deal of work on the basic economics of the money supply process under different policy regimes, and though some of them, notably Brenner and Meltzer, have frequently scolded their colleagues for neglect of these issues, hindsight suggests that they did not recognise the extent to which the problem of implementing a different monetary policy might require a basic overhaul of institutions if it was to be solved, an overhaul that might involve a considerable break with traditional practices, and hence be hard to implement, or that, if they did, they were unable to convince policy-makers to undertake that overhaul at the same time as they adopted monetarist rhetoric.

If central banks, apart from the Bank of Canada, have not in fact succeeded in smoothly slowing down monetary expansion rates in a sustained way, a number of them have nevertheless managed to create contractions in monetary growth rates that have been sharp and persistent enough to bite. Associated with these contractions, as much in Canada as elsewhere, have been the "shifts" of the demand for money function that I discussed earlier in this paper. As the reader will recal1, I argued that these shifts were, in all probability, real phenomena, and not statistical artifacts, that such shifts were nothing new, and that they were probably to be explained, at least in part, by institutional changes which themselves might plausibly be interpreted as a response to monetary policy. I believe that these shifts of the demand for money function, relatively small though they have been, force us to reassess a fundamental tenet of practical monetarism, namely the injunction to fix ex ante a growth rate rule for the money supply, and then ensure adherence to it by taking away from the monetary authorities the discretion to do otherwise. Objections to such a proposal have frequently been cast in terms of the question "How are you going to define the money supply for purposes of implementing this policy?" The answer typically given has been that it doesn't much 
matter, because if the rate of growth of one monetary aggregate is pinned down, all the others will end up behaving consistently, at least on average over the kind of time periods for which stability in monetary policy is really important. That answer is surely valid if one is dealing with an economy in which there is no institutional change in the private sector, but that does not make it as adequate a response to the question as I once thought it did. Suppose we agreed to set a rule for the growth rate of $M$ and that initially we could agree on what assets to include in that aggregate. What if after the rule had been implemented some new asset, for example a new kind of chequing account evolved? Perhaps the demand function for MI as initially defined would then shift, but if ex post we included the new asset in our definition of MI we might still be able to show that the demand for narrow money hadn't "really" shifted, after all.

Such problems would not arise if we were not too specific in laying down the precise definition of money that was to bind policy makers in the future. However, to do that would leave it open to the discretion of someone at some time in the future to decide just how to define the monetary aggregate whose rate of growth was tied down with a rule, and that amounts to giving them the discretion to ignore the rule in question. It is hard to resist the implication that it does not seem to be possible, let alone desirable, to take all discretion away from central banks in a world in which the monetary system is in a state of evolution.

I hasten to add that this does not imply that attempts to implement short-run fine tuning of the economy by way of discretionary movements in interest rates is all of a sudden alright, or that it is fruitless to require central banks to announce target ranges for monetary expansion over, say, one year time horizons, or anything like that. However it does imply that it is 
as a practical matter impossible to prevent central banks doing the wrong things if they so wish by tying them down to a monetary growth rate rule. Unless we can accurately foresee the path that innovations in the financial sector are going to take, someone somewhere is going to have to be granted the discretion to deal with them when they arise. The monetarist injunction not to use monetary policy for fine tuning is not affected by these considerations, but the proposal that the once and for all enactment of a simple rule can lead to that injunction being implemented is undermined. That seems to me to be a rather severe criticism of monetarist policy doctrine.

VI

\section{Concluding Comments}

As the reader will by now have seen, it is my view that the core of Monetarism has consisted of a series of empirical propositions and policy prescriptions, all of which are quite consistent with mainstream economic theory. One can approach the analysis of social questions in terms of the maximising behaviour of individual agents without believing in a stable demand for money function, or a vertical long-run Phillips curve, but evidence that such relationships exist need in no way disturb one's theoretical preconceptions. Although there have been episodes in the monetarist debate where the relevance of mainstream economics to the analysis of such social questions as inflation and unemployment has been vigorously questioned, particularly in Britain, it has mainly been about questions amenable to being settled with reference to empirical evidence, as Mayer (1978) has also argued.

Viewed in this light, I would suggest that, in all but one aspect, the Monetarist debate is as close to being over as an economic controversy ever is. The demand for money function does seem to be more stable over time than the 
early critics of monetarism suggested, while shifts in it have been neither new phenomena, nor of sufficient magnitude to undermine long-run relationships between money and money income. Puzzles about "reverse causation" in the data for countries such as Britain cease to be puzzles when the openness of the economy and the nature of the exchange rate regime are taken account of. There is now much less disagreement than there was about the interaction of real income and inflation: there is a short-run trade off between inflation and unemployment and it does seem to vanish in the long run. Though we should not under-rate the importance of the consensus that has been achieved on the foregoing issues--or neglect to mention explicitly that the consensus in question is not universal--this does not mean that there is now no controversy in macroeconomics. As we have seen two areas remain contentious.

First, one aspect of the monetarist debate remains alive, and that concerns the proper conduct of monetary policy. I doubt that my own view, that the case for governing monetary policy by rules is impossible to sustain in the face of careful consideration of the influence of institutional change on the behaviour over time of the demand for money function, will find a great deal of support among monetarists at present, while I would be surprised to find it regarded as sufficient of a concession to "fine tuning", and it really is no such thing, to satisfy the Keynesians. Thus, I would expect debates about this matter to keep the monetarist controversy alive for a while yet. The other, and in my view far more important, issue has to do with the market-theoretic foundations of macroeconomics. Here I have argued that the issues raised by Lucas and his collaborators are not the issues that have traditionally concerned participants in the monetarist debate and that it is misleading to approach them as if they were. Even so let us hope that the debate 
about the assumptions of clearing markets and rational expectations as a basis for macroeconomics, which as Brian Kantor (1979) has suggested is really about whether Keynes' General Theory carried economics forward or took it on a fruitless detour, will prove as productive as has been the monetarist controversy. 
FOOTNOTES

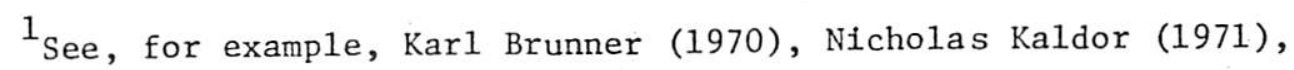
Harry Johnson (1972), Franco Modigliani (1977), Thomas Mayer (1978), Douglas Purvis (1980). This list is far from exhaustive.

2 This is the judgement of Johnson (1962) and Brunner (1970), among others.

${ }^{3}$ Consider, for example, the London Business School model of the U.K. economy (see Jim Ball and Terry Burns (1976)). The Canadian RDX2 model also seems to me to fall into this category.

${ }^{4}$ See, for example, Friedman and Schwartz (1963), Phillip Cagan (1979). Note that such monetarists as Brunner and Meltzer, however, do not use National Bureau techniques. They are mainly associated with the Chicago branch of monetarism.

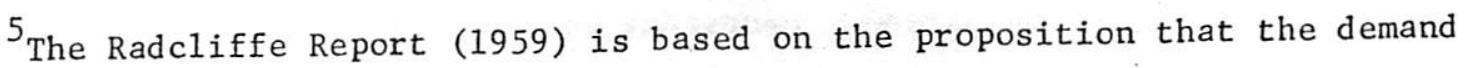
for money function is essentially nonexistent as a stable relationship. For a later statement of the same point of view see Kaldor (1971), or Joan Robinson (1970) .

${ }^{6}$ Note in particular that the Keynesian James Tobin was the author of a pioneering econometric study of the demand for money function. See Tobin (1947). See also his review of Friedman and Schwartz (1963), Tobin (1965), where further econometric estimates of the demand for money function are presented.

${ }^{7}$ I have dealt with the matters taken up here in much greater length in Laidler (1980). 
${ }^{8}$ But as with all such blanket judgements as this there are important exceptions. Irving Fisher's empirical work on the relationship between money and prices presented in The Purchasing Power of Money (1911) is not so far removed from modern monetarism.

${ }^{9}$ But this of course is not to say that Friedman has always paid as much attention to the interest elasticity of the demand for money as his critics might have wished. See for example the various reviews of the monetary history of the United States, but note that the monetarist Allan Meltzer (1965) was as critical on this score as any other reviewer. What we are here dealing with is a characteristic of some of the work of one, albeit the most important, monetarist rather than of monetarism in general.

10 Mayer (1978) argues, correctly I belleve, that Patinkin should not be regarded as a monetarist. This of course is not to deny the important influence that Patinkin's work had on subsequent monetarist analysis. See, for example, Jonson (1976).

${ }^{11}$ There seems to have been a systematic shift in British opinion from the Radcliffe view that money doesn't matter at all, to the view that money matters for real income but not for prices. To trace this development is beyond the scope of this paper. However, the work of Richard Kahn shows clearly that it has taken place. Compare his evidence to the Radcliffe Comittee with, for example, Kahn (1976).

${ }^{12}$ See Peter Wiles (1973) for a particularly extreme version of the soclological approach to inflation.

${ }^{13}$ I have in mind here, in particular, the work of Robert Solow (1969) and James Tobin (1972). 
${ }^{14}$ See Anthony Santomero and John Seater (1979) for a recent and wel1balanced survey of the evidence on these matters.

${ }^{15}$ Notice that in some of his subsequent writings on inflationunemployment interaction Friedman adopts an aggregate supply curve interpretation of the Phillips curve. See E。 G. Friedman (1975)。

${ }^{16}$ See the papers by Armen Alchian, Robert E. Lucas and Leonard Rapping, Donald Gordon and Alan Hines, and Dale Mortensen, a11 in the Phelps volume.

${ }^{17}$ In later work carried out by Brunner and Meltzer and their associates, a version of the aggregate supply curve in which the rate of change of output rather than the level of output affects the rate of inflation appears. This form of the relationship appears to stem from their tendency to treat the expected inflation rate as synonymous with the rate of change of the expected price level. See Brunner and Meltzer (eds。) (1978) and particularly the comments there by Bennett McCallum.

${ }^{18}$ It might be noted that in the aggregate supply curve interpretation of the Phillips curve, the natural unemployment rate becomes a long-run equilibrium concept. In the price reaction function interpretation of the relationship it seems to me to be synonymous with the Keynesian concept of the minimum feasible unemployment rate. For a perceptive discussion of some of the issues involved here see Thomas Wilson (1976)。

${ }^{19}$ I base the following arguments on the papers of Lucas (1975), Thomas Sargent (1976) and Lucas (1977). "The first two of these papers are extremely technical and I am by no means sure that I am doing justice to them in the discussion that follows.

Milton Friedman has pointed out to me that one can only say that errors are random or systematic if one is also specific about both the time at which expectations are formed, and the period for which they are formed. 
If one is now planning for, say a five year horizon, then the rational expectations hypothesis permits the actual value of any variable to deviate systematically from its ex ante expected value over any interval of less than five years. This matter is clearly related to questions raised by adjustment lags, the durabiltty of certain goods, and so on, since the horizon over which a decision taken now is likely to be binding is also presumably the horizon over which a rational agent would seek to form expectations about relevant variables. To the best of my knowledge, the published literature has not recognized this point explicitly, and it deserves much more attention than $I$ have space to give it here.

20 To comment on the empirical work in question, notably that of Robert J. Barro (1978), would take us beyond the scope of this essay.

21 Robert J. Barro (1979) presents a particularly forceful and clearcut statement of what I am calling the "neo-Austrian" view on these matters. Robert Solow (1979) might be regarded as providing a traditional Keynesian rebuttal of this line of argument. Note that questions of the relevant time horizon, raised in fn.19, are again relevant here.

${ }^{22}$ I base the foregoing discussion on conversations and correspondence that I have had with Marcus Miller and Peter Jonson on various occasions. See also Clements and Jonson (1979).

${ }^{23}$ A more extensive account of these matters is given in Laidler (1975), Ch. 1. Note that Brunner, Alex Cuckeirman and Meltzer (1979) provide an analysis of persistent shocks within an aggregate supply curve framework. ${ }^{24}$ Note that Cagan (1978) appears to agree with this point of view, as does Brunner (1978).

25 The locus classicus for pioneering work on the monetary approach to balance of payments analysis is, of course, Frenkel and Johnson (1975). ${ }^{26}$ See, for example, Laidler (1975), Ch. 9 and Jonson (1976). 
${ }^{27}$ It is worth pointing out that I set out much of the foregoing argument in my 1972 Lister Lecture. See Laidler (1975), Ch. 10, where the lecture is reprinted. The argument is developed in further detail in Laidler (1976). ${ }^{28}$ Frenkel (1979) provides a useful and accessible overview of the issues involved here and the evidence on them.

${ }^{29}$ John Helliwell has suggested to me that the application of policy optimization techniques to such models is better regarded as a test of their validity than as a preliminary to actual policy making.

${ }^{30}$ It is worth noting that the Radcliffe Committee (1959) regarded the task of monetary policy to be the achievement of background stability for the economy. Their view differed from the monetarist approach to the same issue in putting interest rates at the centre of the policy making process rather than any monetary aggregate. In the kind of sociological theorising about inflation that was particularly popular in Britain in the early 1970s incomes policy was to be assigned the task of stabilising prices and expectations.

${ }^{31}$ I would emphasise that this is not a new position on my part. It is one that I have consistently taken. Of course the questions about the effectiveness of fiscal policy are important ones for macroeconomists, and the Brown University Conference on Monetarism (see Jerome Stein (1975)) dealt almost exclusively with such issues. I accept Purvis' (1980) judgement that the outcome of that conference was to show beyond a reasonable doubt that "fiscal policy matters" but also his judgement that in retrospect the debate about the effectiveness of fiscal policy has not been the most important one in the monetarist debate, however important an issue it might be in its own right for macroeconomics.

Finally note that the foregoing discussion ignores the question as to whether, even if we had enough knowledge to ensure that fine tuning could be 
used beneficially, the political process would permit it to be used in that way. This question, as Milton Friedman has pointed out to me, is a vital one in any practical debate about activist policies.

${ }^{32}$ of course there has been a considerable ideological content to the monetarist debate and I would not deny that for a moment. Nor would I take the position that there is anything reprehensible about ideological debates per se. I downplay these issues in this paper not because, from broader perspective I would regard them as unimportant, but because my expertise as an economist does not put me in a position to say anything very useful ab out them。

${ }^{33}$ Michael Parkin, Michael Sumner and Robert Jones (1973) is still an admirable source of information about wage and price controls in the British economy. Michael Walker (ed.)(1976) contains much useful information on other countries. Note that the views that I state here about the importance of using wage and price controls, if they are to be used, in conjunction with monetary and fiscal policy, rather than instead of such policies, are those of the McCracken Committee. See McCracken et a1. (1978)。

${ }^{34}$ See Laidler (ed.) (1976), particularly Chapters 7 and 9 for an earlier statement of my own views on the role of the housing market and its interaction with monetary policy and inflation. I readily acknowledge that the source is an obscure one. 


\section{BIBLIOGRAPHY}

Ando, A. and Modigliani, F. (1965) "The Relative Stability of Monetary Velocity and the Investment Multiplier", American Economic Review 55 (September), pp. 693-728.

Ba11, R. J. and Burns, T. (1976) "The Inflationary Mechanism in the U.K. Economy", American Economic Review 66 (September), pp. 478-84. Barro, R. J. (1978) "Unanticipated Money, Output and the Price Level in the United States", Journal of Political Economy 86 (August), pp. 549-581.

Barro, R. J. (1979) "Second Thoughts on Keynesian Economics", American Economic Review 69 (May), papers and proceedings, pp. 54-59. Baumol, W. J. (1952) "The Transactions Demand for Cash: An Inventory Theoretic Approach", Quarterly Journal of Economics 66 (November) pp. 545-56.

Brunner, K. (1961) "The Report of the Commission on the Money and Credit", Journal of Political Economy 69 (December), pp. 605-620.

Brunner, K. (1970) "The Monetarist Revolution in Monetary Theory", Weltwirtschaftlizhes Archiv 105, pp. 1-30.

Brunner, K. (1970) "Issues of Post-Keynesian Monetary Analysis" in Thomas Mayer, 1978.

Brunner, K., Cukierman, A. and Meltzer, A. H., (1979) "Stagflation, Persistent Unemployment and the Permanence of Economic Shocks", Carnegie-Mellon University, mimeo.

Brunner, K. and Meltzer, A. H. (1963) "Predicting Velocity Implications for Theory and Policy", Journal of Finance 18 (May), pp. 319-54. 
Brunner, K. and Meltzer, A. H. (Eds.)(1978), The Inflation Problem, Carnegie-Rochester Public Policy Conference Series (Amsterdam: North-Holland).

Cagan, P. (1978) "Monetarism in Historical Perspective" in Thomas Mayer, 1978. Cagan, P. (1979) Persistent Inflation, Columbia University Press, New York.

Cagan, P. and Schwartz, A. J. (1975) "Has the Growth of Money Substitutes Hindered Monetary Policy?", Journal of Money, Credit and Banking 7 (May), pp. 137-160.

Clements, K. W. and Jonson, P. D. (1979) "Unanticipated Money, Disequilibrium Modelling and Rational Expectations", Economic Letters 2, pp. 303-08. Clower, R. W. (1965) "The Keynesian Counterrevolution: A Theoretical Appraisal" in F. H. Hahn and F. P. R. Brechling, eds., The Theory of Interest Rates (McMillan: London). Deprano, M. and Mayer, T. (1965) "Tests of the Relative Importance of Autonomous Expenditure and Money", American Economic Review 55 (September), pp. 729-52.

Fisher, I. (1911), The Purchasing Power of Money, New York. Friedman, M. (1956) "The Quantity Theory of Money: A Restatement" in M. Friedman, ed., Studies in the Quantity Theory of Money, University of Chicago Press, Chicago.

Friedman, M. (1959) "The Demand for Money: Some Theoretical and Emplrical Results", Journal of Political Economy 67 (June), pp. 327-351.

Friedman, M. (1960), A Program for Monetary Stability, (New York: Fordham University Press).

Friedman, M. (1966) "Interest Rates and the Demand for Money", Journal of Law and Economics 9 (October). 
Friedman, M. (1968) "The Role of Monetary Policy", American Economic Review 58 (March), pp. 1-17.

Friedman, M. (1970) "A Theoretical Framework for Monetary Analysis", Journal of Political Economy 78 (March-Apri1), pp. 193-238.

Friedman, M. (1975), Unemployment Versus Inflation, London Institute of Economic Affairs.

Friedman, M. and Meiselman, D. (1963) "The Relative Stability of Monetary Velocity and the Investment Multiplier in the United States, 1898-1958", in Commission on Money and Credit, Stabilization Policies, Englewood C1iffs, New Jersey (Prentice-Ha11).

Friedman, M. and Schwartz, A. J. (1963a), A Monetary History of the United States, 1867-1960, Princeton, New Jersey, Princeton University Press for the NBER.

Friedman, M. and Schwartz, A. J. (1963b) "Money and Business Cycles", Review of Economics and Statistics 45 (February), supplement, pp. 32-64. Frenke1, J. (1979) "

Paper presented at the Federal Reserve Bank of St. Louis Conference on Monetary Policy, November, University of Chicago mimeo.

Frenke1, J. and Johnson, H. G. (1976), The Monetary Approach to Balance of Payments Theory, (London: George Allen and Unwin). Frisch, H. (1977) "Inflation Theory 1963-1975: A Second Generation Survey", Journal of Economic Literature 15 (December), pp. 1289-1317. Harberger, A. C., ed., (1960), The Demand for Durable Goods, (Chicago: University of Chicago Press).

Harrod, R. F. (1971) "Discussion Paper" in G. Clayton, J. C. Gilbert and R. Sedgewick, Monetary Theory and Monetary Policy in the 1970's, (London: Oxford University Press). 
Hicks, J. R. (1974), The Crisis in Keynesian Economics, Oxford (Basil Blackwell). Johnson, H. G. (1962) "Monetary Theory and Policy", American Economic Review 52 (June), pp. 335-384.

Johnson, H. G. (1972), Inflation and the Monetarist Controversy, DeVries Lectures, 1971 (Amsterdam: North Holland).

Jonson, P. D. (1976a) "Money and Economic Activity in the Open Economy, the United Kingdom 1880-1970", Journal of Political Economy 84 (October), pp. 979-1012.

Jonson, P. D. (1976b) "Money, Prices and Output: An Intregrative Essay", Kredit on Kapital 9, pp. 499-518.

Kahn, R. F. (1976) "Inflation: A Keynesian View", Scottish Journal of Political Economy 23 (February), pp. 11-15.

Kaldor, N. (1970) "The New Monetarism", Lloyd's Bank Review July, pp. 1-18. Kantor, B. (1979) "Rational Expectations and Economic Thought", Journal of Economic Literature 17 (December), pp. 1422-1475.

Laidler, D. (1966) "The Rate of Interest and the Demand for Money: Some Empirical Evidence", Journal of Political Economy 74 (December), pp. $545-55$.

Laidler, D. (1971) "The Influence of Money on Economic Activity: A Survey of Some Current Problems", in G. Clayton, J. C. Gilbert and R. Sedgwick, eds., Monetary Theory and Monetary Policy in the 1970's (London: Oxford University Press).

Laidler, D. (1975), Essays on Money and Inflation, (Manchester: University of Manchester Press, Chicago: University of Chicago Press). Laidler, D. (1976) "Inflation in Britain: A Monetarist Analysis", American Economic Review 76 (September), pp. 485-500. 
Laidler, D. (1976b), (et a1), Study on the Possible Part Played by Certain Primary Non-employment Incomes in the Inflationary Process in the United Kingdom, Commission of the European Communities, Brussels. Laidler, D. (1980) "The Demand for Money in the United States: Yet Again", Carnegie-Rochester Conference Series on Public Policy, forthcoming. Lieberman, C. (1980) "The Long-Run and Short-Run Demand for Money Revisited", Journal of Money, Credit and Banking, forthcoming.

Lipsey, R. G. (1960) "The Relationship Between Unemployment and the Rate of Change of Money Wage Rates in the United Kingdom, 1862-1957", Economica 27, pp. 1-31.

Lucas, R. E., Jr. (1972) "Expectations and the Neutrality of Money", Journal of Economic Theory 4, pp. 103-124.

Lucas, R. E., Jr. (1975) "An Equilibrium Model of the Business Cycle", Journal of Political Economy 83 (November-December), pp. 1113-1144. Lucas, R. E., Jr. (1976) "Econometric Policy Evaluation: A Critique", in K. Brunner and A.H. Meltzer, Carnegie-Rochester Public Policy Conference Series.

Lucas, R. E., Jr. (1977) "Understanding Business Cycles" in K. Brunner and A. H. Meltzer, eds., Stabilization of the Domestic and International Economy, Carnegie-Rochester Conference Series (Amsterdam: North Holland). Mayer, T. (1978), The Structure of Monetarism (New'York: W. W. Norton and Company) .

McCracken, P., et al. (1977), Towards Full Employment and Price Stability

(The McCracken Report), Paris, OECD.

Me1tzer, A. H. (1965) "Monetary Theory and Monetary History", Schweizerische Zeitschrift Volkswirtschaft und Statistik Spring, pp. 409-422.

Meltzer, A. H. (1969) "Money Intermediation and Growth", Journal of Economic Literature 7 (March), pp. 27-56. 
Modigliani, F. (1977) "The Monetarist Controversy, or Should We Forsake Stabilization Policies?", American Economic Review 67 (March), pp. 1-19.

Parkin, J. M., Sumner, M. T. and Jones, R. A. (1972) "A Survey of the Econometric Evidence on the Effects of Incomes Policy on the Rate of Inflation" in J. M. Parkin and M. T. Sumner, eds., Incomes Policy and Inflation (Manchester: University of Manchester Press).

Patinkin, D. (1956), Money, Interest and Prices, Rowe Peterson, New York (second edition, Harper Rowe, 1965).

Patinkin, D. (1969) "The Chicago Tradition of the Quantity Theory and Friedman", Journal of Money, Credit and Banking 1 (February), pp. 46-70. Phelps, E. (1967) "Phillips Curves Expectations of Inflation and Optimal Unemployment Over Time", Economica NS 34 (August), pp. 254-281.

Phelps, E. S. (et a1), (1969), Microeconomic Foundations of Employment and Inflation Theory (New York: W. W. Norton and Co.).

Phillips, A. W. (1958) "The Relation Between Unemployment and the Rate of Change of Money Wage Rates in the United Kingdom, 1861-1957", Economica NS 25 (November), pp. 283-299.

Purvis, D. D. (1980) "Monetarism -- A Review", Canadian Journal of Economics 1 (February), pp. 96-121.

Radcliffe Committee (Committee on the Working of the Monetary System), (1959) Report (London: HMSO).

Reid, M. (1962), Housing and Income, (Chicago: University of Chicago Press). Robinson, J. (1970) "Quantity Theories 01d and New", Journal of Money, Credit and Banking 2 (November), pp. 504-512.

Santomero, A. M. and Seater, J. J. (1978) "The Inflation-Unemployment Trade-0ff: A Critique of the Literature", Journal of Economic Literature 16 (June), pp. 499-544. 
Sargent, T. J. (1976) "A Classical Macroeconomic Model for the United States", Journal of Political Economy 84 (Apri1), pp. 207-238.

Sargent, T. J., Wallace, N. (1975) "Rational Expectations, the Optimal Monetary Instrument and the Optimal Money Supply Rule", Journal of Political Economy 83 (Apri1), pp. 241-54.

Solow, R. M. (1968), "Recent Controversies on the Theory of Inflation: An Eclectic View", in S. Rousseas, ed., Symposium on Inflation - It's Causes, Consequences and Control (New York: The Calvin K. Kazanjian Economics Foundation).

Solow, R. M. (1979) "Alternative Approaches to Macroeconomic Theory:

A Partial View", Canadian Journal of Economics 12 (August), pp. 339-54.

Solow, R. M. (1980) "On Theories of Unemployment", American Economic

Review 70 (March), pp. 1-11.

Sumner, M. T. (1980) "The Operation of Monetary Targets", in K. Brunner and A. H. Meltzer, eds., Carnegie-Rochester Public Policy Conference Series, forthcoming (Amsterdam: North-Holland).

Stein, J. (1976), Monetarism (Amsterdam: North-Holland).

Tobin, J. (1947) "Liquidity Preference and Monetary Policy", Review of Economics and Statistics 29 (May), pp. 124-31.

Tobin, J. (1956) "The Interest Elasticity of Transactions Demand for Cash", Review of Economics and Statistics 38 (August), pp. 241-47.

Tobin, J . (1958) "Liquidity Preference as Behaviour Towards Risk", Review of Economic Studies 25 (February), pp. 65-86.

Tobin, J. (1965) "The Monetary Interpretation of History", American Economic Review 55 (June), pp. 464-85.

Tobin, J. (1972) "Inflation and Unemployment", American Economic Review 62 March, pp. 1-18. 
Wa1ker, M. (Ed.), (1976), The Illusion of Wage and Price Contro1 (Vancouver,

\section{B.C.: Fraser Institute).}

Wiles, P. (1973) "Cost Inflation and the State of Economic Theory", Economic Journal 83, pp. 377-98.

Wilson, T. (1976) "The Natural Rate of Unemployment", Scottish Journal of Political Economy 23 (February), pp 99-107. 